\title{
In Vitro Callus Development on Immature Leaf Explants of Liberica Coffee (Coffea liberica L. cv. Liberika Tungkal Komposit) by the Application of 2.4-D and BAP
}

\author{
Lizawati*, Zulkarnain, Neliyati \\ Department of Agroecotechnology, Faculty of Agriculture, Universitas Jambi \\ Jl. Raya Jambi - Muara Bulian KM 15 Muaro Jambi, Jambi, Indonesia. 36122 \\ *Email: liza_wati@unja.ac.id
}

\begin{abstract}
Conventional vegetative propagation is the process in which new plants are grown from a variety of sources, seeds, cuttings and other parts of the plants. Therefore, the conventional vegetative propagation of liberica coffee by cutting or grafting of stems is hampered by the limited number of stem or branches, which can be used as propagating materials. In addition, the tissue culture technique is another method used to propagate liberica coffee. This study aims to investigate an efficient protocol for embryogenic callus development from leaf explants of Coffea liberica cv. Liberika Tungkal Komposit. The explants used are immature leaves of fully opened liberica coffee. The medium used was Murashige and Skoog (MS) composition supplemented with vitamins, 3\% sucrose and solidified with $0.7 \%$ agar, and the medium $\mathrm{pH}$ was adjusted to $5.8 \pm 0.1$. The experiment was arranged in a factorial randomized block design, and the first factor was 2.4-D (2.0, 3.0, 4.0, and 5.0 ppm) and then the second factor was BAP $(0.0,0.5$, and $1.0 \mathrm{ppm})$. The results showed that the application of 2.4-D and BAP significantly improved the distribution of callus proliferation on cultured explants. The use of $2.0 \mathrm{ppm} 2.4-\mathrm{D}+1.0 \mathrm{ppm}$ BAP resulted in the fastest callus proliferation (19 days after culture initiation). In general, the application of different levels of 2.4-D and BAP successfully induced friable with nodular morphology callus on young leaf explant of liberica coffee. It is believe that the callus has embryogenic capacity and will undergo embryogenesis when transferred to a suitable medium composition.
\end{abstract}

Keywords: benzylamino purine; plant propagation; tissue culture; 2.4-Dichlorophenoxyacetic acid

Articel History: Received 26 December 2019; Received in revised form 17 May 2020; Accepted 18 November 2020; Available online 30 December 2020

How to Cite This Article: Lizawati L, Zulkarnain Z, Neliyati N. 2020. In vitro callus development on immature leaf explants of liberica coffee (Coffea liberica L. cv. Liberika Tungkal Komposit) by the application of 2.4-D and BAP. Biogenesis: Jurnal Ilmiah Biologi. vol 8(2): 111-118. doi: https://doi.org/10.24252/bio.v8i2.11769.

\section{INTRODUCTION}

Coffee is a brewed drink prepared from roasted coffee beans or the the seeds of berries from a certain coffee species, which has a high economic value, and plays an important role as a source of foreign exchange in addition to oil and gas. Indonesian is the fourth largest coffee producing country in the world after Colombia, Brazil and Vietnam. The country export rate is about $12 \%$ of world coffee production, just below Brazil (19.66\%) and Vietnam (18.20\%) (ICO, 2017). This shows that Indonesia plays an important role as a leading coffee producing country in the world.

Different types of coffee plants are grown in different parts of the country: namely robusta, arabica and liberica. Liberica coffee (Coffea liberica Bull. ex Hiern.) is one of the most suitable plant crops grown on peatlands. Unlike arabica and robusta, liberica coffee has a distinctive taste of jackfruit, therefore in some regions it is referred to as jackfruit coffee. This type of coffee has become a high priority commodity that needs to be developed in various regencies such as Tanjung Jabung Barat in Jambi Province, and Kepulauan Meranti in Riau Province (Mawardhi \& Setiadi, 2019). Therefore, it is not surprising that the demand for the seeds of superior clone of liberica coffee continues to grow. Ferry et al. (2015) suggested that Liberika Tungkal Komposit (Libtukom) from Tanjung Jabung Barat, Jambi Province, and Liberoid Meranti-1 (LIM-1) and Liberoid Meranti-2 (LIM-2) from the Kepulauan Meranti, Riau Province are superior liberica clones to be developed on peatland.

Coffea liberica are cross pollinated species, and therefore there is great variability between progenies when the species is seedpropagated. To maintain genetic uniformity within regenerated progenies, liberica coffee can be propagated vegetatively, either by stem 
cutting or grafting. This will ensure that the regenerated plants have similar desirable traits as their parents. However, conventional vegetative propagation of liberica coffee through stem cutting or grafting is hampered by the limited number of stem or branches, which are used as propagation materials.

The tissue culture technique is another method used for liberica coffee propagation, which leads to the production of large amount of relatively uniform seeds within a short period of time (Zulkarnain et al., 2015; Ardiyani et al., 2020). More importantly, the regenerated seeds are pathogen free, or virus contaminants (Ray et al., 2011; Pradhan et al., 2016). The research on an in vitro propagation of coffee has been widely reported such as in arabica coffee (Riyadi \& Tirtoboma, 2004; Arimarsetiowati, 2011; Ibrahim et al., 2013) and robusta coffee (Murni, 2010; Priyono, 2010; Hapsoro et al., 2019; Ibrahim et al., 2019). To the best of our knowledge, this is among a very few reports on the propagation of Coffea liberica through tissue culture technique. This study aims to obtain embryogenic callus development on immature leaf explants of $C$. liberica $\mathrm{cv}$. Liberika Tungkal Komposit by the use of 2.4-D and BAP as the first step in developing an efficient protocol for an in vitro propagation of this species.

\section{MATERIALS AND METHODS}

This research was carried out at the Plant Biotechnology Laboratory, of the Faculty of Agriculture, Universitas Jambi. Sections of immature leaves of $C$. liberica cv. Liberika Tungkal Komposit were used as explant materials. The media used were Murashige and Skoog (1962) composition supplemented with vitamins, $3 \%$ sucrose and solidified with $0.7 \%$ agar. The medium $\mathrm{pH}$ was adjusted to $5.8 \pm 0.1$.

Somatic Callus Induction. Immature coffee leaves were isolated from stock plants maintained in glasshouse. The individual leaves were washed in $100 \mathrm{~mL}$ sterile water with 4 drops of Tween-20 for 20 minutes, and rinsed three times with sterile water. The leaves were then sterilized in 5\% Agrept (a bactericide) solution for 20 minutes, followed by immersion in $1 \% \mathrm{NaOCl}$ solution for 5 minutes while stirring, then rinsed three times with sterile water. In a transfer box, the leaves were dried on sterile tissue paper, place in a sterile petri dish, and cut into sections of approximately 1 $\mathrm{cm}^{2}$. The sections were not included in the mid rib and veins. The explants were immediately cultured on sterile medium in culture flask. One explant was cultured in one flask. The flask containing explants were maintained in culture room with photoperiod of 16 hours, light intensity of $1000-1500$ lux, temperature of $25^{\circ} \mathrm{C}$, and relative humidity of $60 \%$ (Zulkarnain et al., 2013).

Experimental Design. The experiment was arranged in a factorial randomized block design, the first factor was different concentrations of 2.4-D (2.0, 3.0, 4.0 and 5.0 $\mathrm{ppm})$ and the second factor was different concentration of BAP $(0.0,0.5$ and $1.0 \mathrm{ppm})$ (Ahmed et al., 2013). This made 12 treatment combinations, and each combination was repeated 3 times, which resulted in 36 experimental units, and each unit consists of 4 cultures. The parameters observed were span time for callus proliferation (days after culture), percentage of explants forming callus, callus weight, callus size, callus morphology (color, structure and the presence of embryogenic properties).

Data Analysis. The quantitative data (span time for callus proliferation, percentage of explant forming callus, callus weight and size) were statistically analyzed using Duncan's Multiple Range Test at $\alpha=5 \%$, while data on callus morphology (color, structure and the presence of embryogenic properties) were presented descriptively.

\section{RESULTS AND DISCUSSION}

Span time for callus proliferation. The analysis of variance on span time for callus proliferation shows that there is an interaction between 2.4-D and BAP concentrations. The effect of different concentrations of 2.4-D and BAP on span time for callus proliferation is presented in Table 1. 
Table 1. The effect of different concentrations of 2.4-D and BAP on span time for callus proliferation (days after culture).

\begin{tabular}{cccr}
\hline $\begin{array}{c}2.4-\mathrm{D} \\
(\mathrm{ppm})\end{array}$ & $\begin{array}{c}\text { BAP } \\
(0.0 \mathrm{ppm})\end{array}$ & $\begin{array}{c}\text { BAP } \\
(0.5 \mathrm{ppm})\end{array}$ & \multicolumn{1}{c}{$\begin{array}{c}\text { BAP } \\
(1.0 \mathrm{ppm})\end{array}$} \\
\hline 2.0 & $26.22(\mathrm{~A}) \mathrm{a}$ & $23.44(\mathrm{~A}) \mathrm{ab}$ & $19.89(\mathrm{C}) \mathrm{b}$ \\
3.0 & $27.11(\mathrm{~A}) \mathrm{a}$ & $22.78(\mathrm{~A}) \mathrm{ab}$ & $21.66(\mathrm{BC}) \mathrm{b}$ \\
4.0 & $23.66(\mathrm{~A}) \mathrm{b}$ & $23.11(\mathrm{~A}) \mathrm{b}$ & $33.33(\mathrm{~A}) \mathrm{a}$ \\
5.0 & $23.22(\mathrm{~A}) \mathrm{a}$ & $26.44(\mathrm{~A}) \mathrm{a}$ & $25.77(\mathrm{~B}) \mathrm{a}$
\end{tabular}

Notes: Numbers followed by the same uppercase in the same columns and the same lowercase in the same rows indicating a non-significant difference based on Duncan's Multiple Range Test at $\alpha=0.05$.

The results presented in Table 1 shows that the application of 2.4-D and BAP significantly promotes span time for callus proliferation. The application of $2.0 \mathrm{ppm} 2.4-\mathrm{D}+1.0 \mathrm{ppm}$ BAP is reported to be the best combination to boost callus proliferation on the young immature leaf of explants of liberica coffee (19-23 days after culture). In contrast, explants cultured on medium supplemented with of $4.0 \mathrm{ppm}$ 2.4-D + $1.0 \mathrm{ppm}$ BAP is reported to be the slowest in callus proliferation rate (26-33 days after culture).

The immature leaf explant of $C$. liberica cv. Liberika Tungkal Komposit is capable of developing callus when cultured on media supplemented with 2.4-D and BAP. In addition, the formation of callus started at the cut end of explants proceeded by the formation of swelling. The formation of callus on the surface of wounded tissues was likely due to the action of tissue recovery stimulus. In line with Ikeuchi et al. (2017) and Fehér (2019) that callus developed was due to dynamic hormone synthesis and distribution within the callus tissue, also transcriptional changes.

Percentage of explant forming callus. All cultured explants responds well to the application of 2.4-D and BAP. Regardless of the concentration applied, all cultured explants are reported to form callus (Table 2). This indicates that the number of explant developing callus does not depend on the concentration of either 2.4-D or BAP or the interaction between.
Table 2. The effect of different concentrations of 2.4-D and BAP on the percentage of explant forming callus (12 weeks after culture).

\begin{tabular}{llll}
\hline $2.4-\mathrm{D}$ & BAP & BAP & BAP \\
$(\mathrm{ppm})$ & $(0.0 \mathrm{ppm})$ & $(0.5 \mathrm{ppm})$ & $(1.0 \mathrm{ppm})$ \\
\hline 2.0 & 100 & 100 & 100 \\
3.0 & 100 & 100 & 100 \\
4.0 & 100 & 100 & 100 \\
5.0 & 100 & 100 & 100 \\
\hline
\end{tabular}

The reaction showed by explants within 19 days of culture (which was the quickest response) on the application of $2.0 \mathrm{ppm}$ 2.4-D +1.0 ppm BAP indicated that $C$. liberica leaf explants responded well to growth regulators. The concentrations used were thought to be ideal balance to give rise to callus. Ikeuchi et al. (2013) suggested that a balanced amount of auxin and cytokinin will encourage callus formation. On the application of $4.0 \mathrm{ppm} 2.4-\mathrm{D}$ +1.0 ppm BAP it took 33 days for explants to form callus. In line with Irene et al. (2019) findings that higher concentration levels of 2.4D recorded reduced induction rates of Coffea arabica.

Despite the time required for callus proliferation, all the cultured explants responded well to all combination of growth regulators tested, indicated by $100 \%$ explants forming callus. In addition, the callus formation was made possible because immature leaf tissues were used as culture materials. The immature explants of actively growing tissues at the beginning of growth period were generally more responsive to an in vitro culture, in such a way that the cell regeneration process can take place quickly (Wan Nur Syuhada et al., 2016; Hapsoro et al., 2020). In contrast, the presence of growth regulators, particularly 2.4$\mathrm{D}$, were very important in stimulating callus proliferation on the explants.

Callus weight. The statistical analysis on callus weight does not show any interaction between 2.4-D and BAP concentrations. As a single factor, the application of 2.4-D does not show any significant effect on callus growth. In contrast, the application of BAP significantly increased callus weight (Table 3). 
Table 3. The effect of different concentrations of 2.4-D and BAP on callus fresh weight $(\mathrm{g})$ (12 weeks after culture).

\begin{tabular}{llll}
\hline $\begin{array}{l}2.4-\mathrm{D} \\
(\mathrm{ppm})\end{array}$ & $\begin{array}{l}\text { BAP } \\
(0.0 \mathrm{ppm})\end{array}$ & $\begin{array}{l}\text { BAP } \\
(0.5 \mathrm{ppm})\end{array}$ & $\begin{array}{l}\text { BAP } \\
(1.0 \mathrm{ppm})\end{array}$ \\
\hline 2.0 & $1.07(\mathrm{~A}) \mathrm{a}$ & $0.68(\mathrm{~B}) \mathrm{ab}$ & $0.53(\mathrm{~A}) \mathrm{b}$ \\
3.0 & $0.75(\mathrm{~A}) \mathrm{a}$ & $0.67(\mathrm{~B}) \mathrm{a}$ & $0.59(\mathrm{~A}) \mathrm{a}$ \\
4.0 & $0.98(\mathrm{~A}) \mathrm{a}$ & $1.10(\mathrm{~A}) \mathrm{a}$ & $0.39(\mathrm{~A}) \mathrm{b}$ \\
5.0 & $0.86(\mathrm{~A}) \mathrm{a}$ & $0.71(\mathrm{AB}) \mathrm{a}$ & $0.48(\mathrm{~A}) \mathrm{a}$
\end{tabular}

Notes: Numbers followed by the same uppercase in the same columns and the same lowercase in the same rows indicating a non-significant difference based on Duncan's Multiple Range Test at $\alpha=0.05$.

The results presented on Table 3 shows that the heaviest weight of fresh callus $(1.10 \mathrm{~g})$ is obtained on explants cultured on medium supplemented with $4.0 \mathrm{ppm} 2.4-\mathrm{D}+0.5 \mathrm{ppm}$ $\mathrm{BAP}$, and this is significantly heavier than the callus proliferated on medium with $2.0 \mathrm{ppm}, 3.0$ ppm or $5.0 \mathrm{ppm}$ 2.4-D in combination with the same BAP level. In the absence of BAP, the heaviest weight of fresh callus $(1.07 \mathrm{~g})$ was obtained in the application of $2.0 \mathrm{ppm} 2.4-\mathrm{D}$, but the difference is not significant to the callus proliferated on medium with $3.0 \mathrm{ppm}$ to 5.0 ppm 2.4-D in the absence of BAP.

The application of 2.4-D had no significant effect on the callus weight. In contrast, BAP showed a significant effect, and the interaction of these two growth regulators, however, did not result in significant effect on the average callus weight. The average callus weight on medium with $2.0 \mathrm{ppm}$ to $5.0 \mathrm{ppm}$ 2.4-D without BAP was relatively the same to those callus proliferated on medium with the same 2.4-D + $0.5 \mathrm{ppm}$ BAP, but higher than those proliferated on the same 2.4-D + $1.0 \mathrm{ppm}$ BAP. These results showed the inhibiting effect of BAP on callus growth. The difference in callus weight was likely due to the difference in responses showed by cells within coffee leaves to growth regulators. Batista-Santos et al. (2011) claim that each cell had its own sensitivity to the gene regulators given within the Coffea genus. In addition, the time of cell division was not the same due to the difference in cell cycle.

The difference in callus weight was caused by difference in ratio between low-level cytokinin (BAP) 0-1 ppm and high-level auxin (2.4-D) 2-5 ppm. This was in accordance with the results of Shofiyani \& Damajanti (2017) which reported that in Kaempferia galanga callus, the application of 2.4-D without BAP resulted in greater callus weight than with BAP addition. The 2.4-D was believed to play a role in the secretion of $\mathrm{H}^{+}$through cell wall. The acidification of cell wall caused the capture of $\mathrm{K}^{+}$which resulted in the decrease of water potential within the cells. As a result, water easily penetrate the cell and result in the enlargement of cell due to water accumulation.

Callus size. The data analysis showed that there is no interaction between 2.4-D and BAP effect on the size of callus formed on explants cultured on all combination of these plant hormones. The application of 2.4-D as single factor does not show any significant effect, however, BAP as single factor was reported to significantly improve callus size. The largest size $\left(3.39 \mathrm{~cm}^{2}\right)$ is formed on explants cultured on BAP-free medium, which is significantly larger than those formed on explants cultured on medium with 1.0 ppm BAP (Table 4).

Table 4. The effect of different concentrations of 2.4-D and BAP on callus size $\left(\mathrm{cm}^{2}\right)$ (12 weeks after culture).

\begin{tabular}{llll}
\hline $2.4-\mathrm{D}$ & BAP & BAP & BAP \\
$(\mathrm{ppm})$ & $(0.0 \mathrm{ppm})$ & $(0.5 \mathrm{ppm})$ & $(1.0 \mathrm{ppm})$ \\
\hline 2.0 & $3.42(\mathrm{~A}) \mathrm{a}$ & $2.97(\mathrm{~A}) \mathrm{a}$ & $2.26(\mathrm{~A}) \mathrm{a}$ \\
3.0 & $3.75(\mathrm{~A}) \mathrm{a}$ & $2.77(\mathrm{~A}) \mathrm{a}$ & $2.61(\mathrm{~A}) \mathrm{a}$ \\
4.0 & $3.56(\mathrm{~A}) \mathrm{a}$ & $3.47(\mathrm{~A}) \mathrm{a}$ & $1.82(\mathrm{~A}) \mathrm{b}$ \\
5.0 & $2.82(\mathrm{~A}) \mathrm{a}$ & $2.67(\mathrm{~A}) \mathrm{a}$ & $1.98(\mathrm{~A}) \mathrm{a}$
\end{tabular}

Notes: Numbers followed by the same uppercase in the same columns and the same lowercase in the same rows indicating a non-significant difference based on Duncan's Multiple Range Test at $\alpha=0.05$.

The results presented on Table 4 showed that the effect of $2.0 \mathrm{ppm}, 3.0 \mathrm{ppm}$ and $5.0 \mathrm{ppm}$ 2.4-D does not significantly increase callus size when combined with any level of BAP. However, when 4.0 ppm 2.4-D is applied in combination with $1.0 \mathrm{ppm}$ BAP, the size of callus is greatly decreased.

The largest callus size when applying 2.0 ppm to 5.0 ppm 2.4-D without BAP was 3.39 $\mathrm{cm}^{2}$ which was not significantly different from the callus proliferated with the application of $2.0 \mathrm{ppm}$ to $5.0 \mathrm{ppm}$ 2.4-D in combination with $0.5 \mathrm{ppm}$ BAP $\left(2.97 \mathrm{~cm}^{2}\right)$, but significantly larger than the callus developed on explants cultured on medium with $2.0 \mathrm{ppm}$ to $5.0 \mathrm{ppm}$ 2.4-D in combination with 1.0 ppm BAP (1.12 $\mathrm{cm}^{2}$ ). This showed that higher concentration of BAP might inhibit callus growth, and therefore decreased callus size. The difference in the size 
of the calluses was due to the different ability of the tissues to absorb water and nutrients that ultimately affect the growth of the calluses. The size of the callus can also be influenced by the duration of the observation, and the longer the time of observation the greater the size of the callus when nutrients in the media id available. Kartika et al. (2019) reported that in vitro callus development was also the result of interaction between growth regulating factors, explants sources, culture media, and plant genotypes.

Table 5. The effect of different concentrations of 2.4-D and BAP on callus color (12 weeks after culture)

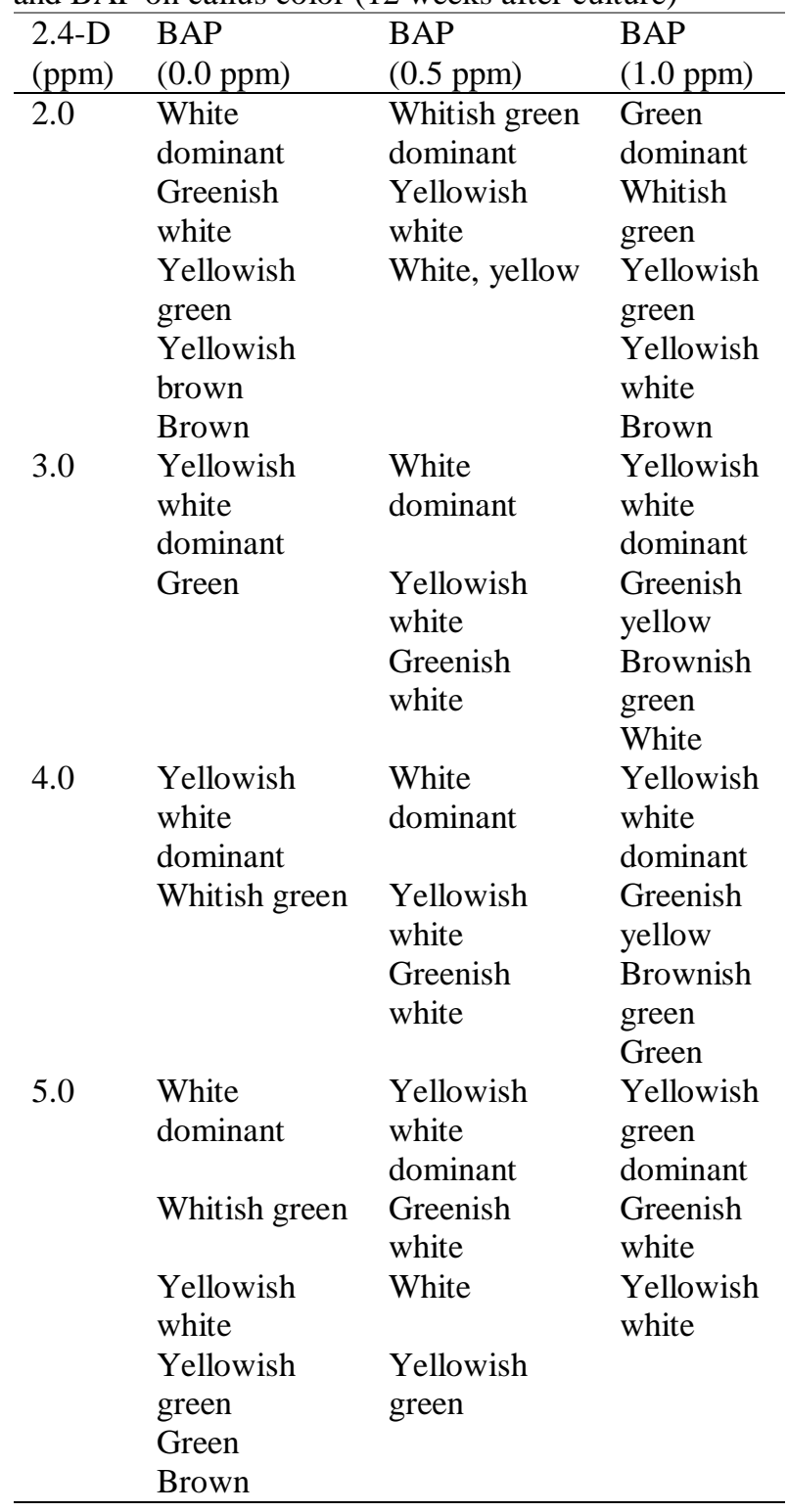

Callus morphology. The morphology of callus is grouped into the following criteria: color, structure, and the presence or absence of embryogenic properties. The qualitative information on color and structure of callus are presented on Table 5 and 6 , while embryogenic properties are presented in Fig. 1.

The color of callus proliferated on the surface of immature leaf explants of $C$. liberica cv. Liberika Tungkal Komposit varies widely from white, greenish white, yellowish white, whitish green, yellowish green, green, brown, and yellowish brown. This showed that the appearance of callus is much dependent on the balance of 2.4-D and BAP concentrations employed in culture medium.

Table 6. The effect of different concentrations of 2.4-D and BAP on callus structure (12 weeks after culture)

\begin{tabular}{|c|c|c|c|}
\hline $\begin{array}{l}\text { 2.4-D } \\
(\mathrm{ppm})\end{array}$ & $\begin{array}{l}\text { BAP } \\
(0.0 \mathrm{ppm})\end{array}$ & $\begin{array}{l}\text { BAP } \\
(0.5 \mathrm{ppm})\end{array}$ & $\begin{array}{l}\text { BAP } \\
(1.0 \mathrm{ppm})\end{array}$ \\
\hline 2.0 & $\begin{array}{l}\text { Friable and } \\
\text { compact, } \\
\text { dominated } \\
\text { by compact }\end{array}$ & $\begin{array}{l}\text { Friable and } \\
\text { compact, } \\
\text { dominated } \\
\text { by compact }\end{array}$ & $\begin{array}{l}\text { Friable and } \\
\text { compact, } \\
\text { dominated } \\
\text { by compact }\end{array}$ \\
\hline 3.0 & $\begin{array}{l}\text { Friable and } \\
\text { compact, } \\
\text { dominated } \\
\text { by friable }\end{array}$ & $\begin{array}{l}\text { Friable and } \\
\text { compact, } \\
\text { dominated } \\
\text { by friable }\end{array}$ & $\begin{array}{l}\text { Friable and } \\
\text { compact, } \\
\text { dominated } \\
\text { by compact }\end{array}$ \\
\hline 4.0 & $\begin{array}{l}\text { Friable and } \\
\text { compact, } \\
\text { dominated } \\
\text { by friable }\end{array}$ & $\begin{array}{l}\text { Friable and } \\
\text { compact, } \\
\text { dominated } \\
\text { by friable }\end{array}$ & $\begin{array}{l}\text { Friable and } \\
\text { compact, } \\
\text { dominated } \\
\text { by compact }\end{array}$ \\
\hline 5.0 & $\begin{array}{l}\text { Friable and } \\
\text { compact, } \\
\text { dominated } \\
\text { by friable }\end{array}$ & $\begin{array}{l}\text { Friable and } \\
\text { compact, } \\
\text { dominated } \\
\text { by friable }\end{array}$ & $\begin{array}{l}\text { Friable and } \\
\text { compact, } \\
\text { dominated } \\
\text { by friable }\end{array}$ \\
\hline
\end{tabular}

Different color of callus showed different levels of their developmental stage at different concentrations of growth regulators. Lizawati (2012) suggested that the color differences that occur in callus showed different levels of callus development, and this was influenced by the concentration of growth regulators applied to growing media. Furthermore, some callus were brown due to the release of phenolic compounds. Browning in callus was frequently due to the metabolism of phenolic compounds and peroxidase activities, which were released by wounded tissues, and inhibit tissue growth and even causing the death of the tissues (Abohatem et al., 2011; Kaewubon et al., 2015, Irshad et al., 2017).

The greenish white, yellowish white and yellowish green colors appeared due to the 
decomposition of chlorophyll. The decomposition of chlorophyll can occur due to the loss of polarization, which was important in the formation of chlorophyll, or due to photooxidation, resulting in loss of $\mathrm{Mg}^{2+}$ in the subculture process. White callus was an embryogenic tissue that does not contain chloroplasts, but has a high starch content. In jatropha plant (Jatropha curcas), white callus proliferated from hypocotyl and cotyledon explants were proved to be embryogenic that lead to somatic embryos development (Zulkarnain \& Lizawati, 2011).

The data presented on Table 6 shows that the majority of callus morphology is dominated by friable, though compact structure is also discovered in some treatments. The friable callus consists of tubular, loose, irregular and easily separated cell mass, while compact callus consists of nodular cells with dense structure. Visual presentation of callus morphology is presented in Fig. 1.

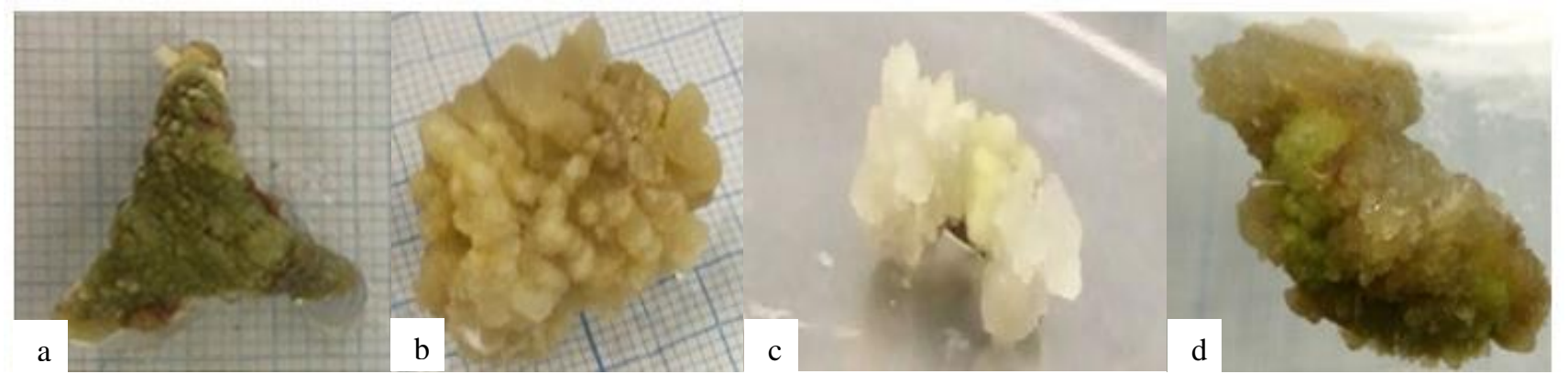

Fig. 1. Callus morphology of $C$. liberica cv. Liberika Tungkal Komposit: a. Callus mass showing friable structure; b. Callus mass showing compact structure; $c$. Friable and nodular callus from medium with 2.4-D alone; d. Friable and nodular callus on medium with 2.4-D + BAP.

Generally, the application of 2.4-D and BAP can lead to the formation of friable and nodular callus (58\%) and compact callus $(42 \%)$. Furthermore, callus with friable and nodular morphology is expected to develop into embryogenic callus mass that will eventually regenerated somatic embryos when subcultured into appropriate medium.

The difference in callus morphology shows the variation of the effect of using growth regulators. According to Harahap et al. (2019) and Ming et al. (2019), friable callus was composed by long-tubular and unorganized cells in which the structure of cells mass was irregular and easily separated, whereas compact callus was composed by nodular cells with a dense structure. The soft friable or easily separated callus mass was a good morphology hence it facilitated rapid cell division into individual cells (Jayaraman et al., 2014). It will also increase oxygen aeration between cells, and therefore facilitated an attempt to increase callus growth through suspension culture. In contrast, in compact callus the opportunity for cells to grow further and develop into intact plants (plantlets) was greater.
The application of different levels of 2.4-D and BAP was able to induce the proliferation of friable and nodular callus, but not regenerate embryos. This is because the regenerated callus presumably lacks of embryogenic capacity. The formation of nonembryogenic calluses in this study was suspected because the tested level of 2.4-D or BAP could not increase the sensitivity of the cells within the immature leaf of liberica coffee. And as such, specific genes that play an important roles in the induction of embryogenic callus were not activated as cell cycle was not reactivated.

\section{CONCLUSION}

The application of different levels of 2.4-D and BAP significantly improved the callus proliferation on immature leaf explants of $C$. liberica cv. Liberika Tungkal Komposit. The fastest callus proliferation (averagely $19-23$ days after culture initiation) was achieved on explants cultured on medium supplemented with $2.0 \mathrm{ppm} 2.4-\mathrm{D}+1.0 \mathrm{ppm}$ BAB. The heaviest callus $(1.10 \mathrm{~g})$ was generated on explants cultured on medium supplemented with $4.0 \mathrm{ppm}$ 2.4-D + $0.5 \mathrm{ppm}$ BAP. Meanwhile, the largest callus size was obtained 
on explants cultured on medium supplemented with 4.0ppm 2.4-D. The application of 2.0, 3.0, 4.0 and $5.0 \mathrm{ppm}$ 2.4-D in combination with 0.0 , 0.1 and $0.5 \mathrm{ppm}$ BAP effectively induced the formation of friable and nodular callus on immature leaf explants of $C$. liberica $\mathrm{cv}$. Liberika Tungkal Komposit. However, the formation of embryogenic callus was unsuccessful.

\section{REFERENCES}

Abohatem M, Zouine J, El Hadrami I. 2011. Low concentrations of BAP and high rate of subcultures improve the establishment and multiplication of somatic embryos in date palm suspension cultures by limiting oxidative browning associated with high levels of total phenols and peroxidase activities. Scientia Horticulturae. vol 130(1): 344-348. doi: https://doi.org/10.1016/j.scienta.2011.06.045.

Ahmed W, Feyissa T, Disasa T. 2013. Somatic embryogenesis of a coffee (Coffea arabica L.) hybrid using leaf explants. The Journal of Horticultural Science and Biotechnology. vol 88(4); 469-475.

Ardiyani F, Utami ESW, Purnobasuki H, Paramita SA. 2020. Development and regeneration of somatic embryos from leaves-derived calli of Coffea liberica. Biodiversitas. vol 21(12): 5829-5834. doi: https://doi.org/10.13057/biodiv/d211246.

Arimarsetiowati R. 2011. Pengaruh auksin 2.4-D dan sitokinin 2-ip terhadap pembentukan embriogenesis somatik langsung pada eksplan daun Coffea arabica L. Pelita Perkebunan. vol 27(2): 68-76. doi:

https://doi.org/10.22302/iccri.jur.pelitaperkebunan. v27i2.146.

Batista-Santos P, Lidon FC, Fortunato A, Leitão AE, Lopes E, Partelli F, Ribeiro AI, Ramalho JC. 2011. The impact of cold on photosynthesis in genotypes of Coffea spp.-photosystem sensitivity, photoprotective mechanisms and gene expression. Journal of Plant Physiology. vol 168(8): 792-806. doi: https://doi.org/10.1016/j.jplph.2010.11.013.

Fehér A. 2019. Callus, dedifferentiation, totipotency, somatic embryogenesis: what these terms mean in the era of molecular plant biology?. Frontiers in Plant Science. vol 10: 1-11. doi: https://doi.org/10.3389/fpls.2019.00536.

Ferry Y, Supriadi H, Ibrahim MSD. 2015. Teknologi budi daya tanaman kopi: Aplikasi pada perkebunan rakyat. Jakarta: Pusat Perpustakaan dan Penyebaran Teknologi Pertanian, Kementerian Pertanian RI.

Hapsoro D, Setiawan D, Hamiranti R, Yusnita Y. 2019. Pengaruh 2-iP, BA, 2, 4-D, dan TDZ pada embriogenesis somatik in vitro kopi robusta unggul Lampung. Jurnal Agrotek Tropika. vol 7(3): 527 537. doi: http://dx.doi.org/10.23960/jat.v7i3.3545.

Hapsoro D, Hamiranti R, Yusnita Y. 2020. In vitro somatic embryogenesis of superior clones of robusta coffee from Lampung, Indonesia: Effect of genotypes and callus induction media. Biodiversitas. vol 21(8): 3811-3817. doi: https://doi.org/10.13057/biodiv/d210849.

Harahap F, Diningrat DS, Poerwanto R, Nasution NEA, Hasibuan RFM. 2019. In vitro callus induction on Sipahutar pineapple (Ananas comosus L.) from North Sumatra Indonesia. Pakistan Journal of Biological Sciences. vol 22(11): 518-526. doi: https://dx.doi.org/10.3923/pjbs.2019.518.526.

Ibrahim MSD, Hartati RS, Rubiyo R, Purwito A, Sudarsono S. 2013. Induksi kalus embriogenik dan daya regenerasi kopi arabika menggunakan 2, 4Dichlorophenoxyacetic Acid dan 6-Benzyladenine. Jurnal Tanaman Industri dan Penyegar. vol 4(2): 91-98.

doi: http://dx.doi.org/10.21082/jtidp.v4n2.2013.p91-98.

Ibrahim MSD, Randriani E, Sari L, Nuranini A. 2019. Radiosensitivitas kalus embriogenik kopi robusta BP 436 terhadap iradiasi sinar gamma. Jurnal Tanaman Industri dan Penyegar. vol 6(1): 41-50. doi:

http://dx.doi.org/10.21082/jtidp.v6n1.2019.p41-50.

Ikeuchi M, Sugimoto K, Iwase A. 2013. Plant callus: mechanisms of induction and repression. The Plant Cell. vol 25(9): 3159-3173. doi: https://doi.org/10.1105/tpc.113.116053.

Ikeuchi M, Iwase A, Rymen B, Lambolez A, Kojima M, Takebayashi Y, Heyman J, Watanabe S, Seo M, Veylder LD, Sakakibara H, Sugimoto K. 2017. Wounding triggers callus formation via dynamic hormonal and transcriptional changes. Plant Physiology. vol 175(3): 1158-1174. doi: https://doi.org/10.1104/pp.17.01035.

International Coffee Organization. 2017. All Exporting Countries Total Production Crop Years. England: International Coffee Organization. http://www.ico.org/.

Irene WM, Alumiro HL, Asava KK, Agwanda CO, Anami SE. 2019. Effects of genotype and plant growth regulators on callus induction in leaf cultures of Coffea arabica L. F1 hybrid. Journal of Plant Biochemistry and Physiology. vol 7(2): 1-12. doi: 10.35248/2329-9029.19.7.236.

Irshad M, He B, Liu S, Mitra S, Debnath B, Li M., Rizwan HM, Qiu D. 2017. In vitro regeneration of Abelmoschus esculentus L. Cv. Wufu: Influence of anti-browning additives on phenolic secretion and callus formation frequency in explants. Horticulture, Environment, and Biotechnology. vol 58(5): 503-513. doi: https://doi.org/10.1007/s13580-017-0301-3.

Jayaraman S, Daud NH, Halis R, Mohamed R. 2014. Effects of plant growth regulators, carbon sources and $\mathrm{pH}$ values on callus induction in Aquilaria malaccensis leaf explants and characteristics of the resultant calli. Journal of Forestry Research. vol 25(3): 535-540. doi: https://doi.org/10.1007/s11676-014-0492-8. 
Kartika E, Lizawati L, Zulkarnain Z. 2019. In Vitro callus formation from male inflorescences of oil palm (Elaeis guineensis Jacq.) by The Application of Picloram. Analele Universităţii din Oradea, Fascicula Biologie. vol 26(1): 57-61.

Kaewubon P, Hutadilok-Towatana N, da Silva JAT, Meesawat U. 2015. Ultrastructural and biochemical alterations during browning of pigeon orchid (Dendrobium crumenatum Swartz) callus. Plant Cell, Tissue and Organ Culture (PCTOC). vol 121(1): 53-69. doi: https://doi.org/10.1007/s10535018-0769-4

Lizawati L. 2012. Induksi kalus embriogenik dari eksplan tunas apikal tanaman jarak pagar (Jatropha curcas L.) dengan penggunaan $2.4 \mathrm{D}$ dan TDZ. Bioplantae. vol 1(2): 75-87.

Mawardhi AD, Setiadi D. 2019. Strategi pemanfaatan lahan gambut melalui pengembangan agroforestri kopi liberika (Coffea liberica). In proceeding Seminar Nasional Lahan Suboptimal. October 1819, 2018. Palembang: UNSRI Press. ISBN: 978 979-587-801-8. pp. 43-51.

Ming NG, Binte Mostafiz S, Johon NS, Abdullah Zulkifli NS, Wagiran A. 2019. Combination of plant growth regulators, maltose, and partial desiccation treatment enhance somatic embryogenesis in selected Malaysian rice cultivar. Plants. vol 8(6): 1 15. doi: https://dx.doi.org/10.3390\%2Fplants8060144.

Murashige T, Skoog F. 1962. A revised medium for rapid growth and bioassays with tobacco tissue cultures. Physiologia Plantarum. vol 15: 473-97. doi: https://doi.org/10.1111/j.13993054.1962.tb08052.x.

Murni P. 2010. Embriogenesis somatik pada kultur in vitro daun kopi robusta (Coffea canephora var. Robusta chev.). Biospecies. vol 2(2): 22-26.

Pradhan S, Regmi T, Ranjit M, Pant B. 2016. Production of virus-free orchid Cymbidium aloifolium (L.) Sw. by various tissue culture techniques. Heliyon. vol 2(10): 1-14. doi: https://dx.doi.org/10.1016/j.heliyon.2016.e00176.

Priyono P. 2010. Evaluation of somatic embryogenesis ability in robusta coffee (Coffea canephora Pierre). Pelita Perkebunan. vol 26(2): 77-89. doi: 10.22302/iccri.jur.pelitaperkebunan.v26i2.126.

Ray BP, Hassan L, Nasiruddin KM. 2011. In vitro regeneration of brinjal (Solanum melongena L.). Bangladesh Journal of Agricultural Research. vol 36(3): 397-406. doi: https:doi.org/10.3329/bjar.v36i3.9268.

Riyadi I, Tirtoboma. 2004. Pengaruh 2.4-D terhadap induksi embrio somatik kopi arabika. Buletin Plasma Nutfah. vol 10(2): 82-89. doi: http://dx.doi.org/10.21082/blpn.v10n2.2004.p8289.

Shofiyani A, Damajanti N. 2017. Pengaruh 2.4-D (Asam Diklorofenoksi Asetat) dan BAP (Benzyl Amino Purin) terhadap Proliferasi Kalus dan Produksi Metabolit Sekunder dari Kalus Kencur (Kaemferia galanga L.). Jurnal Ilmu Kefarmasian Indonesia. vol 15(2): 180-185. doi: https://doi.org/10.35814/jifi.v15i2.414.

Wan Nur Syuhada WS, Rasid OA, Parveez GKA. 2016. Evaluation on the effects of culture medium on regeneration of oil palm plantlets from immature embryos (IE). Journal of Oil Palm Research. vol 28(2): 234-239. doi: https://doi.org/10.21894/jopr.2016.2802.12.

Zulkarnain Z, Lizawati L. 2011. Proliferasi kalus dari eksplan hipokotil dan kotiledon tanaman jarak pagar (Jatropha curcas L.) pada pemberian 2, 4-D. Jurnal Natur Indonesia. vol 14(1): 19-25. doi: http://dx.doi.org/10.31258/jnat.14.1.19-25.

Zulkarnain Z, Neliyati N, Lizawati L. 2013. Callus proliferation from immature leaf explants of durian (Durio zibethinus Murr. cv. Selat) with the addition of Picloram and BAP. Jurnal Hortikultura Indonesia. vol 4(3): 107-114.

Zulkarnain Z, Tapingkae T, Taji A. 2015. Applications of in vitro techniques in plant breeding. In: AlKhayri J, Jain S, Johnson D. (eds) Advances in plant breeding strategies: Breeding, biotechnology and molecular tools. New York: Springer Cham. doi: https://doi.org/10.1007/978-3-319-22521-0_10. 